\title{
Shewanella profunda sp. nov., isolated from deep marine sediment of the Nankai Trough
}

\author{
Laurent Toffin, ${ }^{1,2}$ Adeline Bidault, ${ }^{1}$ Patricia Pignet, ${ }^{3}$ Brian J. Tindall, ${ }^{4}$ \\ Alexander Slobodkin, ${ }^{5}$ Chiaki Kato ${ }^{2}$ and Daniel Prieur ${ }^{1}$ \\ ${ }^{1}$ UMR 6539, Centre National de la Recherche Scientifique et Université de Bretagne \\ Occidentale, Technopôle Brest-Iroise, Place Nicolas Copernic, 29280 Plouzané, France \\ ${ }^{2}$ Marine Ecosystems Research Department, Japan Marine Science and Technology Centre, \\ 2-15 Natsushima-cho, Yokosuka 237-0061, Japan \\ ${ }^{3}$ Laboratoire de Microbiologie et de Biotechnologie des Extrêmophiles, Département de \\ Valorisation des Produits, IFREMER, Centre de Brest, BP 70, 29280 Plouzané, France \\ ${ }^{4} \mathrm{DSMZ}$ - Deutsche Sammlung von Mikroorganismen und Zellkulturen GmbH, Mascheroder \\ Weg 1b, D-38124 Braunschweig, Germany \\ ${ }^{5}$ Institute of Microbiology, RAS Prospekt 60 Let Oktyabrya 7/2, 117312 Moscow, Russia
}

Correspondence

Laurent Toffin

toffin@jamstec.go.jp
Very few micro-organisms have been recovered from deep subseafloor sediments. Desulfovibrio profundus was the first piezophilic species to be isolated from deep marine deposits collected in the Japan Sea (Bale et al., 1997). Recently, a novel methanogenic species, Methanoculleus submarinus, was isolated from Nankai Trough sediment (Mikucki et al., 2003). The genus Shewanella comprises Gram-negative, facultative anaerobes that belong to the $\gamma$-Proteobacteria (MacDonell \& Colwell, 1985) and is typically one of the

Published online ahead of print on 13 April 2004 as DOI 10.1099/ ijs.0.03007-0.

The GenBank/EMBL/DDBJ accession number for the $16 \mathrm{~S}$ rRNA gene sequence of Shewanella profunda $\mathrm{LT}_{13} \mathrm{a}^{\top}$ is AY445591.

An electron micrograph and details of the growth behaviour and fatty acid and polar lipid compositions of strain $\mathrm{LT}_{13} \mathrm{a}^{\top}$ are available as supplementary material in IJSEM Online. deep-sea bacterial genera (DeLong et al., 1997). This genus includes psychrophilic and mesophilic species originating mainly in freshwater and marine habitats (Jensen et al., 1980; Semple \& Westlake, 1987; Myers \& Nealson, 1988; Brettar \& Hölfe, 1993; Nogi et al., 1998; Venkateswaran et al., 1998; Ivanova et al., 2003). Thermophilic Shewanellalike bacteria were recently cultivated (Ghosh et al., 2003). The genus Shewanella was divided into two subgenera on the basis of phylogenetic structure, growth properties in relation to pressure, and polyunsaturated fatty acid production (Kato \& Nogi, 2001).

The novel isolate was obtained from a sediment sample that was collected $4 \cdot 15 \mathrm{~m}$ below the seafloor at a water depth of $4790.7 \mathrm{~m}$ in the Pacific Ocean at the Nankai Trough offshore from Japan (site 1173: $32^{\circ} 14^{\prime} 7^{\prime} \mathrm{N} 135^{\circ}$ $1 \cdot 5^{\prime}$ E) between 28 and 07 June 2000 on Leg 190 of the Ocean Drilling Program (site 1173). All details of the 
environmental conditions, sampling and subsampling procedures have been reported previously (Cragg et al., 1992a, b; Parkes et al., 1995; Moore et al., 2001).

Enrichment cultures were conducted anaerobically in medium containing the following $\left(\mathrm{l}^{-1}\right): 30 \mathrm{~g}$ sea salts (Sigma), 2 g yeast extract (Difco), 2 g peptone (Difco) and $0.5 \mathrm{mg}$ resazurine. The medium was adjusted to $\mathrm{pH} 7 \cdot 0$ and autoclaved. Sterile additions were as follows: $10 \mathrm{ml}$ $1 \mathrm{M} \mathrm{NaHCO}_{3}, 1 \mathrm{~g} \mathrm{CH}_{3} \mathrm{COONa} .3 \mathrm{H}_{2} \mathrm{O}, 1 \mathrm{ml}$ trace elements solution (Widdel \& Bak, 1992), $1 \mathrm{ml}$ vitamin solution (Widdel \& Bak, 1992), $1 \mathrm{ml} \mathrm{0.01 \% (w/v)} \mathrm{thiamine} \mathrm{(Widdel}$ \& Bak, 1992), $1 \mathrm{ml} \mathrm{0.005 \% (w/v)} \mathrm{vitamin} \mathrm{B}_{12}$ (Widdel \& Bak, 1992), $1 \mathrm{ml}$ growth factor (Pfennig et al., 1981), $0.3 \mathrm{~g}$ $\mathrm{KH}_{2} \mathrm{PO}_{4}, 0.5 \mathrm{mg}$ sodium selenate and $0.5 \mathrm{mg}$ sodium tungstate. The final $\mathrm{pH}$ of the medium was about $6 \cdot 8$. Medium was distributed into vials and initial vial preparation involved sequential evacuation and gassing with $\mathrm{H}_{2} / \mathrm{CO}_{2}(20: 80, \mathrm{v} / \mathrm{v})$ at $200 \mathrm{kPa}$. The medium was then reduced by using $0.5 \mathrm{~g}$ sodium sulphide $\mathrm{l}^{-1}$. Sediment suspensions were inoculated $(10 \%$ final, v/v) into the medium and incubated at $25{ }^{\circ} \mathrm{C}$. Growth of motile, rodshaped micro-organisms was observed in enrichment cultures after 2 days incubation at $25^{\circ} \mathrm{C}$. Positive cultures were transferred at least three times at $10 \%$ inoculum into fresh medium and spread on plates containing $1 \%(\mathrm{w} / \mathrm{v})$ agar (Difco). On agar plates, colonies were circular and transparent; they were $1-2 \mathrm{~mm}$ in diameter after 3-5 days incubation at $30^{\circ} \mathrm{C}$. Old cultures were slightly pinkish. One isolate was purified and designated LT13a ${ }^{\mathrm{T}}$ (=DSM $15900^{\mathrm{T}}=\mathrm{JCM} 12080^{\mathrm{T}}$ ).

Isolate $\mathrm{LT}_{13} \mathrm{a}^{\mathrm{T}}$ was grown routinely in the following medium (YP) containing the following $\left(\mathrm{l}^{-1}\right): 23 \mathrm{~g} \mathrm{NaCl}$, $3 \mathrm{~g} \mathrm{MgCl}_{2}, 0 \cdot 15 \mathrm{~g} \mathrm{CaCl}_{2}, 0 \cdot 5 \mathrm{~g} \mathrm{KCl}, 4 \mathrm{~g} \mathrm{Na}_{2} \mathrm{SO}_{4}, 1$ g yeast extract (Difco), $2 \mathrm{~g}$ peptone (Difco), $3.6 \mathrm{~g}$ PIPES buffer and $0.25 \mathrm{~g} \mathrm{KH}_{2} \mathrm{PO}_{4}$. The $\mathrm{pH}$ of the medium was adjusted to $7 \cdot 2$ before autoclaving. Unless indicated otherwise, cultures were incubated aerobically at $30^{\circ} \mathrm{C}$ and atmospheric pressure. Stock cultures of isolate $\mathrm{LT}_{13} \mathrm{a}^{\mathrm{T}}$ were stored in culture medium at $4{ }^{\circ} \mathrm{C}$. For long-term storage, pure cultures were stored at $-80{ }^{\circ} \mathrm{C}$ in the same medium containing $20 \%(\mathrm{v} / \mathrm{v})$ glycerol.

The isolate was tested for Gram-staining, cell size, morphology [using phase-contrast microscopy (model $\mathrm{BH} 2$; Olympus) and electron microscopy (JEM 100 CX II; JEOL) after negative staining with $2 \%(\mathrm{w} / \mathrm{v})$ uranyl acetate] and for cytochrome oxidase and catalase $\left(3 \% \mathrm{H}_{2} \mathrm{O}_{2}\right)$.

Nankai Trough strain $\mathrm{LT} 13 \mathrm{a}^{\mathrm{T}}$ appeared as single rods that were approximately $0.5-0.7 \times 2.5-3.5 \mu \mathrm{m}$ (see Supplementary Fig. A in IJSEM Online) during the exponential phase of growth. Cells were motile by means of a single polar flagellum (see Supplementary Fig. A in IJSEM Online). They did not form endospores and spores were not produced in any phase of growth under any growth conditions tested. Cells stained Gram-negative and were oxidase-positive and catalase-negative.
To determine the optimum temperature, $\mathrm{pH}$ and $\mathrm{NaCl}$ concentration, cells were grown in YP medium. Growth at the following temperatures was tested: 4, 10, 15, 20, 25, 30,37 and $40{ }^{\circ} \mathrm{C}$. Growth at the following $\mathrm{NaCl}$ concentrations was tested: $0,5,10,15,20,30,40,50,60,70,80$ and $90 \mathrm{~g} \mathrm{l}^{-1}$. Growth at the following $\mathrm{pH}$ values was tested: $3 \cdot 0,4 \cdot 0,5 \cdot 0,5 \cdot 5,6 \cdot 0,6 \cdot 5,7 \cdot 0,7 \cdot 5,8 \cdot 0,8 \cdot 5,9 \cdot 0$ and $10 \cdot 0$, as described by Widdel \& Bak (1992). The effect of the following hydrostatic pressures on growth rates of strain LT13 $\mathrm{a}^{\mathrm{T}}$ was determined: $0 \cdot 1,10,20,30,40$ and $50 \mathrm{MPa}$ at $30{ }^{\circ} \mathrm{C}$, as previously described (Kato et al., 1995).

Utilization of carbohydrates (listed in Table 1) as catabolic substrates was tested aerobically in a modified YP liquid medium from which carbon sources were omitted. The following carbon sources were tested: gelatin, maltose, glucose, fructose, galactose, arabinose, cellobiose, lactose, mannitol, mannose, rhamnose, sorbitol, sucrose, xylose, yeast extract, peptone and tryptone (each at $0.2 \%$, $\mathrm{w} / \mathrm{v})$; formate, pyruvate, propionate, butyrate, valerate,

Table 1. Differential phenotypic characterization of $S$. profunda strain $\mathrm{LT}_{13} \mathrm{a}^{\mathrm{T}}$ in comparison with related Shewanella species

1, S. profunda LT13a $\mathrm{a}^{\mathrm{T}}$; 2, S. putrefaciens $(n=10) ; 3$, S. baltica $(n=5) ; 4, S$. oneidensis $(n=5)$. Data are from this study, Venkateswaran et al. (1999) and Brettar et al. (2002). +, Positive reaction; $(+)$, weak reaction; - , no reaction. Numbers indicate percentages of strains that test positive. NA, No data available.

\begin{tabular}{|c|c|c|c|c|}
\hline Characteristic & 1 & 2 & 3 & 4 \\
\hline Optimal growth temp. $\left({ }^{\circ} \mathrm{C}\right)$ & $25-30$ & $25-35$ & $20-25$ & $25-35$ \\
\hline \multicolumn{5}{|l|}{ Growth at/in: } \\
\hline $4{ }^{\circ} \mathrm{C}$ & + & + & + & 20 \\
\hline $37^{\circ} \mathrm{C}$ & + & + & - & + \\
\hline $40^{\circ} \mathrm{C}$ & - & - & - & 60 \\
\hline $0 \% \mathrm{NaCl}$ & + & + & + & + \\
\hline $6 \% \mathrm{NaCl}$ & + & 100 & + & 40 \\
\hline \multicolumn{5}{|l|}{ Production of: } \\
\hline Amylase & + & 0 & - & 0 \\
\hline Gelatinase & + & 0 & + & 100 \\
\hline Acetoin & + & - & - & - \\
\hline Ornithine decarboxylase & + & - & - & - \\
\hline \multicolumn{5}{|l|}{ Utilization of: } \\
\hline D-Galactose & - & 100 & - & 80 \\
\hline Sucrose & - & 40 & 100 & 0 \\
\hline Maltose & $(+)$ & 60 & 100 & 0 \\
\hline Lactose & - & 30 & - & 0 \\
\hline Cellobiose & - & - & 100 & NA \\
\hline D-Sorbitol & $(+)$ & 0 & NA & 0 \\
\hline Succinate & + & 60 & - & 100 \\
\hline Fumarate & + & 60 & - & 80 \\
\hline Citrate & + & 0 & 100 & 0 \\
\hline DL-Malate & - & 0 & 75 & 0 \\
\hline DL-Lactate & + & 60 & NA & 100 \\
\hline
\end{tabular}


isovalerate, glutamate, caproate, caprylate, malate, succinate, isobutyrate, heptanoate, 2-methylbutyrate, 3methylbutyrate, monomethylamine, acetate, lactate, propanol, ethanol and methanol (each at $10 \mathrm{mM}, \mathrm{v} / \mathrm{v}$ ). The strain was also characterized by using the API 20E identification system (bioMérieux) at $30^{\circ} \mathrm{C}$, according to the manufacter's instructions.

Anaerobic growth tests were performed in a modified YP liquid medium prepared with $5 \mathrm{~g} \mathrm{NaCl} \mathrm{l}^{-1}$ and without $\mathrm{Na}_{2} \mathrm{SO}_{4}$, with $0.02 \%(\mathrm{w} / \mathrm{v})$ yeast extract to stimulate growth. L-Cystine $\left(10 \mathrm{~g} \mathrm{l}^{-1}\right), \mathrm{CO}_{2}(100 \mathrm{kPa})$, thiosulphate, tetrathionate, sulphate, sulphite, succinate, nitrate, nitrite, molybdate, glycine, fumarate, trimethylamine- $\mathrm{N}$-oxide, manganese dioxide and ferric iron were tested as electron acceptors at final concentrations of 2 and $10 \mathrm{mM}$, with $10 \mathrm{mM}$ lactate as the electron donor and carbon source. Sulphur reduction was also tested in overlay gel agar by using the modified techniques of Moser \& Nealson (1996) and Lucas et al. (2002). Preparation of amorphous Fe(III) oxide and $\mathrm{Fe}(\mathrm{II})$ determination were performed as described earlier (Slobodkin et al., 1999). Compounds were considered to be electron acceptors if they supported growth of strain LT13 $\mathrm{a}^{\mathrm{T}}$ on defined marine medium. Strain ${ }_{\mathrm{LT} 13 \mathrm{a}^{\mathrm{T}}}$ used oxygen, nitrate, ferric iron, fumarate and cystine as terminal electron acceptors with lactate as the electron donor, but did not use trimethylamine- $\mathrm{N}$-oxide, DMSO, manganese dioxide, thiosulphate, sulphite, tetrathionate, sulphate, elemental sulphur, molybdate, nitrite, succinate, glycine or carbon dioxide.

Fermentation of various carbohydrates was tested by using modified YP medium from which carbon sources had been omitted. The following carbohydrates were tested: glucose, arabinose, cellobiose, fructose, galactose, lactose, maltose, mannitol, mannose, rhamnose, xylose, sucrose, sorbitol, Casamino acids, tryptone, peptone and yeast extract (each at $0 \cdot 2 \%, \mathrm{w} / \mathrm{v}$ ), and pyruvate, lactate and malate (each at 10 and $30 \mathrm{mM}$ ).

Positive cultures were transferred twice (10\% inoculum) into the test media to confirm growth and were compared with the control cultures without the added carbon or electron acceptor. Growth observed within $48-72 \mathrm{~h}$ was considered as a positive result. The organic acid metabolic end products that were produced during fermentation of pyruvate were analysed by HPLC (Alliance 2690; Waters) as described by Wery et al. (2001).

For nitrite and ammonium analysis, cultures were grown anaerobically in solidified YP medium supplemented with $5 \mathrm{mM} \mathrm{KNO}$ and incubated at $37^{\circ} \mathrm{C}$. Reduction of nitrate and nitrite was determined by using the indophenol blue method of Koroleff (1969) and Solorzano (1969). $\mathrm{H}_{2} \mathrm{~S}$ production was evaluated by adding $500 \mu \mathrm{l}$ of a solution of $\mathrm{CuSO}_{4}(5 \mathrm{mM})$ and $\mathrm{HCl}(50 \mathrm{mM})$ to a $250 \mu \mathrm{l}$ culture grown at $30^{\circ} \mathrm{C}$. The dark-brown precipitate, demonstrating the presence of sulphide, was compared with uninoculated medium incubated under the same conditions.
Respiratory lipoquinones and polar lipids were extracted from $100 \mathrm{mg}$ freeze-dried cell material by using the twostage method described by Tindall (1990a, b). Respiratory quinones were extracted by using methanol/hexane (Tindall, 1990b) and polar lipids were extracted by adjusting the remaining methanol/0.3\% aqueous $\mathrm{NaCl}$ phase (containing the cell debris) to give a chloroform/methanol/ $0 \cdot 3 \%$ aqueous $\mathrm{NaCl}$ mixture $(1: 2: 0 \cdot 8$, by vol.). The extraction solvent was stirred overnight and the cell debris was pelleted by centrifugation. Polar lipids were recovered into the chloroform phase by adjusting the chloroform/ methanol $/ 0 \cdot 3 \%$ aqueous $\mathrm{NaCl}$ mixture to a ratio of $1: 1: 0 \cdot 9$ (by vol.).

Respiratory lipoquinones were separated into their different classes (menaquinones and ubiquinones) by TLC on silica gel (Macherey-Nagel; part no. 805023), using hexane/tertbutylmethylether $(9: 1, \mathrm{v} / \mathrm{v})$ as solvent. UV-absorbing bands corresponding to menaquinones or ubiquinones were removed from the plate and further analysed by HPLC. This step was carried out on LDC Analytical HPLC equipment (Thermo Separation Products) fitted with a reverse-phase column (Macherey-Nagel; $2 \mathrm{~mm} \times 125 \mathrm{~mm}$, $\left.3 \mu \mathrm{m}, \mathrm{RP}_{18}\right)$ using methanol as the eluent. Respiratory lipoquinones were detected at $269 \mathrm{~nm}$.

The major respiratory quinones present comprised both ubiquinones and menaquinones. The major ubiquinones present were ubiquinone $7\left(\mathrm{Q}_{7}\right)(21 \%)$ and $\mathrm{Q}_{8}(79 \%)$. The major menaquinones present were menaquinone $7\left(\mathrm{MK}_{7}\right)$ (24\%), $\mathrm{MK}_{8}(1 \cdot 7 \%)$, monomethylmenaquinone $7\left(\mathrm{MMK}_{7}\right)$ $(70 \%)$ and $\mathrm{MMK}_{8}(4 \cdot 3 \%)$. The presence of ubiquinones, menaquinones and methylmenaquinones has been reported in members of the genus Shewanella. The presence of $\mathrm{Q}_{7}$ and $\mathrm{Q}_{8}$ as the dominant ubiquinones, but also $\mathrm{MK}_{7}$ and $\mathrm{MMK}_{7}$ among the naphthoquinones, has previously been reported only in members of the genus Shewanella (Akagawa-Matsushita et al., 1992; Nogi et al., 1998; Venkateswaran et al., 1999; Bozal et al., 2002; Satomi et al., 2003).

Polar lipids were separated by two-dimentional silica-gel TLC (Macherey-Nagel; part no. 818135). The first direction was developed in chloroform/methanol/water $(65: 25: 4$, by vol.); the second was developed in chloroform/methanol/ acetic acid/water ( $80: 12: 15: 4$, by vol.). Total lipid material and specific functional groups were detected by using dodecamolybdophosphoric acid (total lipids), Zinzadze reagent (phosphate), ninhydrin (free amino groups), periodic acid-Schiff stain ( $\alpha$-glycols), Dragendorff's reagent (quaternary nitrogen) and anisaldehyde/sulphuric acid (glycolipids).

Fatty acids were analysed as their methyl ester derivatives, which were prepared from $10 \mathrm{mg}$ dry cell material. Cells were subjected to differential hydrolysis to detect esterlinked and non-ester-linked (amide-bound) fatty acids (B. J. Tindall, unpublished results). Fatty acid methyl esters were analysed by GC using a $0 \cdot 2 \mu \mathrm{m} \times 25 \mathrm{~m}$ non-polar 
capillary column and flame-ionization detection. The run conditions were as follows: injection and detector port temperature, $300{ }^{\circ} \mathrm{C}$; inlet pressure, $60 \mathrm{kPa}$; split ratio, $50: 1$; injection volume, $1 \mu \mathrm{l}$; temperature program, $130-310^{\circ} \mathrm{C}$ at a rate of $4{ }^{\circ} \mathrm{C} \min ^{-1}$.

The major polar lipids present were phosphatidylethanolamine and phosphatidylglycerol (see Supplementary Fig. C in IJSEM Online). Virtually no data are available on the polar lipid composition of Shewanella species, although unpublished work (G. Stöcklmair \& B. J. Tindall) indicates that the presence of phosphatidylethanolamine and phosphatidylglycerol as the main phospholipids is not atypical of members of this genus. Furthermore, it would appear that both of these compounds resolve into subspots in the two-dimensional thin-layer chromatograms. This is in contrast to the polar lipids of Escherichia coli, for example, where the dominant compounds are also phosphatidylglycerol and phosphatidylethanolamine, but do not resolve into two spots (B. J. Tindall, unpublished results).

The fatty acids comprised straight-chain (saturated and unsaturated), branched-chain and hydroxy fatty acids (see Table 2 and Supplementary Table, available in IJSEM Online). These were predominantly $3-\mathrm{OH}$ fatty acids,

Table 2. Fatty acid composition (\%) of various Shewanella species

1, S. profunda $\mathrm{LT}_{13 \mathrm{a}^{\mathrm{T}}} ; 2, \quad$ S. putrefaciens ATCC $8071^{\mathrm{T}}$ (Venkateswaran et al., 1999); 3, S. baltica OS155 ${ }^{\mathrm{T}}$, described as $S$. baltica NCTC $10735^{\mathrm{T}}$ by Ziemke et al. (1998) and Brettar et al. (2002); 4, S. oneidensis ATCC $700550^{\mathrm{T}}$ (Brettar et al., 2002). ND, No data.

\begin{tabular}{|c|c|c|c|c|}
\hline Fatty acid & 1 & 2 & 3 & 4 \\
\hline \multicolumn{5}{|c|}{ Straight-chain fatty acids: } \\
\hline $14: 0$ & $4 \cdot 0$ & $2 \cdot 3$ & $2 \cdot 2$ & $2 \cdot 6$ \\
\hline $15: 0$ & $4 \cdot 3$ & $3 \cdot 2$ & $7 \cdot 8$ & $4 \cdot 7$ \\
\hline $16: 0$ & $13 \cdot 3$ & $19 \cdot 1$ & $4 \cdot 3$ & $14 \cdot 8$ \\
\hline $17: 0$ & $0 \cdot 8$ & $1 \cdot 5$ & $0 \cdot 6$ & $2 \cdot 8$ \\
\hline $18: 0$ & ND & $2 \cdot 1$ & $\mathrm{ND}$ & $1 \cdot 1$ \\
\hline \multicolumn{5}{|c|}{ Terminally branched fatty acids: } \\
\hline $13: 0$-iso & $6 \cdot 4$ & $2 \cdot 5$ & $12 \cdot 4$ & $2 \cdot 5$ \\
\hline $14: 0$-iso & ND & $0 \cdot 3$ & $1 \cdot 6$ & $2 \cdot 3$ \\
\hline $15: 0$-iso & $15 \cdot 1$ & $21 \cdot 1$ & $14 \cdot 3$ & $25 \cdot 4$ \\
\hline $16: 0$-iso & ND & $0 \cdot 1$ & $0 \cdot 2$ & $1 \cdot 4$ \\
\hline $17: 0$-iso & ND & $1 \cdot 7$ & $0 \cdot 5$ & $1 \cdot 7$ \\
\hline \multicolumn{5}{|c|}{ Monounsaturated fatty acids: } \\
\hline $15: 1 \omega 6 c$ & $0 \cdot 7$ & $0 \cdot 2$ & $2 \cdot 2$ & $0 \cdot 3$ \\
\hline $16: 1 \omega 7 c$ & $30 \cdot 4$ & $29 \cdot 6$ & $24 \cdot 1$ & $23 \cdot 3$ \\
\hline $16: 1 \omega 9 c$ & $2 \cdot 9$ & $3 \cdot 5$ & $1 \cdot 6$ & $2 \cdot 1$ \\
\hline $17: 1 \omega 6 c$ & ND & 0.9 & $1 \cdot 4$ & $1 \cdot 5$ \\
\hline $17: 1 \omega 8 c$ & $5 \cdot 9$ & $6 \cdot 7$ & $11 \cdot 0$ & $8 \cdot 0$ \\
\hline $18: 1 \omega 7 c$ & $1 \cdot 8$ & $6 \cdot 0$ & $0 \cdot 8$ & $5 \cdot 7$ \\
\hline $18: 1 \omega 9 c$ & $1 \cdot 5$ & $3 \cdot 8$ & $0 \cdot 8$ & $2 \cdot 9$ \\
\hline
\end{tabular}

some of which were presumably amide-bound. Comparison with the fatty acid composition published previously indicates that the overall pattern is typical of members of this genus that have been examined to date. However, authors use different methods of analysing the fatty acids, so the results cannot be compared directly. On the basis of the fatty acid analyses reported previously by several authors, as well as the fact that much of the available literature is incomplete with respect to the presence of hydroxy fatty acids or $20: 5 \omega 3 c$, we can only state that the fatty acid composition of strain LT13 $\mathrm{a}^{\mathrm{T}}$ is based on all cellular components, including lipids and lipopolysaccharides and that mass spectrometry did not indicate that $20: 5 \omega 3 c$ was present. This is, to our knowledge, the first report in which the presence of both hydroxy fatty acids and $20: 5 \omega 3 c$ has been taken into consideration. The presence of hydroxy fatty acids, some of which appear to be amide-linked, is also consistent with the presence of a lipopolysaccharide and these components, though not always reported, may be of importance in differentiating members of the genus Shewanella (Makemson et al., 1997; Leonardo et al., 1999; Bozal et al., 2002; Brettar et al., 2002). Consistent with other reports on organisms similar to Shewanella putrefaciens, no polyunsaturated fatty acids $(20: 5 \omega 3 c)$ were detected.

Genomic DNA of strain LT13a ${ }^{\mathrm{T}}$ was isolated by using the procedure described by Erauso et al. (1992). The G+C content of the genomic DNA was determined by HPLC according to the Deutsche Sammlung von Mikroorganismen und Zellkulturen (DSMZ; Braunschweig, Germany). The genomic DNA G+C content of strain $\mathrm{LT}_{13} \mathrm{a}^{\mathrm{T}}$ is $44.9 \mathrm{~mol} \%$, a value in accordance with that of Shewanella species studied to date (Venkateswaran et al., 1999).

Sequencing reactions were performed by using a Thermo Sequenase primer cycle sequencing kit (Amersham Biosciences) and an automatic DNA analysis system (LICOR 4000; Scientec) according to the manufacturers' protocols. A total of $1334 \mathrm{nt}$ from the 16S rRNA gene was sequenced as described previously (Moore et al., 1995). Phylogenetic analysis was performed by using the software package ARB (Ludwig et al., 2004). Distance analysis [using the correction factor of Jukes \& Cantor (1969)] and clustering with neighbour-joining (Saitou \& Nei, 1987) and maximum-parsimony analysis (Lake, 1987) revealed that strain $\mathrm{LT} 13 \mathrm{a}^{\mathrm{T}}$ affiliated within the genus Shewanella within the $\gamma$-Proteobacteria (Fig. 1). Strain $\mathrm{LT}_{13} \mathrm{a}^{\mathrm{T}}$ was related more closely to $S$. putrefaciens ( $98 \%$ similarity), an environmental bacterium isolated from aquatic environments (Brettar \& Höfle, 1993), sediments (Myers \& Nealson, 1990) and oilfields (Semple \& Westlake, 1987). Strain $\mathrm{LT}_{13 \mathrm{a}^{\mathrm{T}}}$ was also related closely to Shewanella oneidensis $(97 \%)$ and Shewanella baltica (96\%). Strain LT13a ${ }^{\mathrm{T}}$ and S. putrefaciens clustered together in 98 and $70 \%$ of bootstrap trees (by distance and parsimony, respectively) (Fig. 1).

Strains included in the DNA-DNA hybridization experiments were S. putrefaciens DSM $6067^{\mathrm{T}}$, S. baltica DSM 


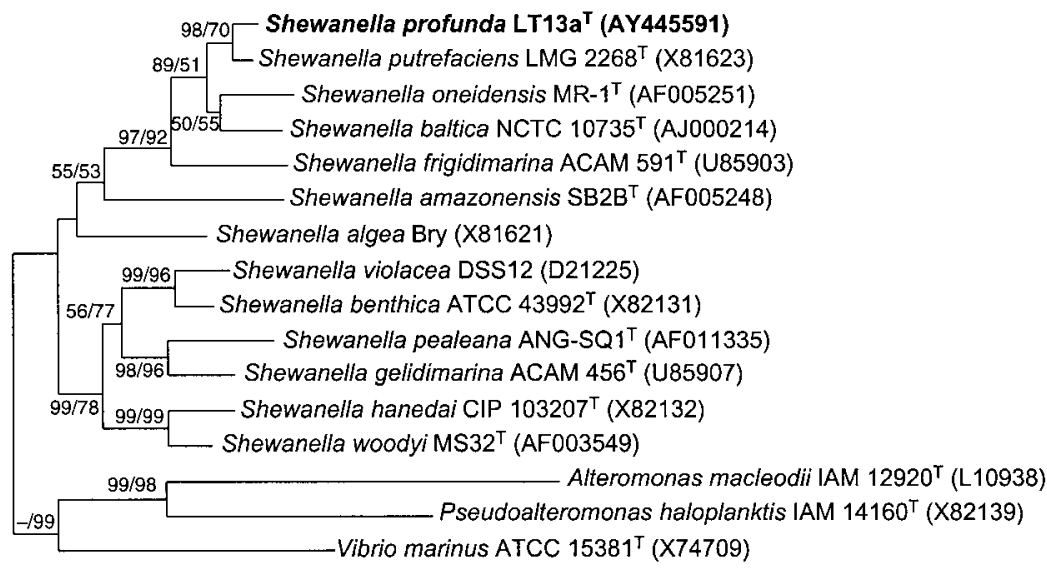

$\underline{0.01}$
Fig. 1. Phylogenetic relationships of $S$. profunda (strain $\mathrm{LT}_{13} \mathrm{a}^{\mathrm{T}}$ ) and other Shewanella species produced by neighbour-joining with the Jukes-Cantor correction factor (Jukes \& Cantor, 1969). The topologies of the trees were evaluated by maximum-parsimony (Lake, 1987) by using the program DNAPARS. The 16S rRNA gene sequence of strain $\mathrm{LT}_{13} \mathrm{a}^{\mathrm{T}}$ was aligned with other 16S rRNA gene sequences from the Ribosomal Database Project (Maidak et al., 2001) and GenBank. Numbers at branch nodes are bootstrap values based on 1000 replicates (distance and parsimony; Felsenstein, 1985) and are shown for branches with $>50 \%$ bootstrap support. The tree was generated with Alteromonas macleodii IAM 12920', Pseudoalteromonas haloplanktis IAM $14160^{\top}$ and Vibrio marinus ATCC $15381^{\top}$ as the outgroup. Bar, 0.01 expected changes per sequence position.
$9439^{\mathrm{T}}(\mathrm{DSMZ})$ and $S$. oneidensis strain $\mathrm{MR}-1^{\mathrm{T}}(=\mathrm{CIP}$ $106686^{\mathrm{T}}$ ) [Collection de l'Institut Pasteur (CIP), Paris, France]. All strains were cultured aerobically at $30{ }^{\circ} \mathrm{C}$ with agitation, according to the instructions of DSMZ and CIP. Levels of genetic relatedness were determined by performing DNA-DNA dot-blot hybridization experiments as reported previously, with modifications (Marteinsson et al., 1995). DNA probes were labelled by using an enhanced chemifluorescence random-prime labelling kit (Amersham Biosciences). The level of hybridization is the mean level of binding for at least four replicates. The results of DNA-DNA hybridization experiments revealed that similarity for strain $\mathrm{LT}_{13 \mathrm{a}^{\mathrm{T}}}$ was $<20 \%$ with the three closest reference strains (S. putrefaciens DSM $6067^{\mathrm{T}}$, S. baltica DSM $9439^{\mathrm{T}}$ and $S$. oneidensis strain $\mathrm{MR}-1^{\mathrm{T}}$ ), indicating that strain $\mathrm{LT}_{13 \mathrm{a}^{\mathrm{T}}}$ is a novel species of Shewanella (Stackebrandt \& Goebel, 1994).

When different taxonomic parameters were compared, strain $\mathrm{LT}_{13} \mathrm{a}^{\mathrm{T}}$ was found to differ from the Shewanella species that have been described (Table 1). Strain LT13a ${ }^{T}$ differs from its nearest phylogenetic neighbours as follows: (i) strain LT13 $\mathrm{a}^{\mathrm{T}}$ was able to produce acetoin, amylase and ornithine decarboxylase, unlike S. putrefaciens, S. baltica or S. oneidensis; (ii) strain $\mathrm{LT} 13 \mathrm{a}^{\mathrm{T}}$ can be distinguished from $S$. putrefaciens by means of gelatinase activity; (iii) strain LT13 $\mathrm{a}^{\mathrm{T}}$ was able to use citrate as sole carbon source; (iv) strain LT13a $\mathrm{a}^{\mathrm{T}}$ did not produce $\mathrm{H}_{2} \mathrm{~S}$ from thiosulphate and elemental sulphur and did not reduce trimethylamine$\mathrm{N}$-oxide, but reduced cystine to $\mathrm{H}_{2} \mathrm{~S} ;$ (v) the optimal hydrostatic pressure for growth was $10 \mathrm{MPa}$; and (vi) levels

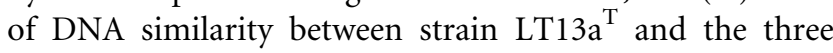
closest neighbours were $<20 \%$. On the basis of physiological properties, in combination with DNA-DNA hybridization with the closest described relatives, strain $\mathrm{LT} 13 \mathrm{a}^{\mathrm{T}}$ represents a separate species within the genus Shewanella.
Consequently, we propose to name this novel species Shewanella profunda sp. nov., with strain $\mathrm{LT}_{13 \mathrm{a}^{\mathrm{T}}}$ as the type strain.

\section{Description of Shewanella profunda sp. nov.}

Shewanella profunda (L. fem. adj. profunda from the deep).

Cells are Gram-negative, rod-shaped and motile by means of a single polar flagellum. Facultatively anaerobic heterotroph. Oxidase-, amylase-, gelatinase-, ornithine decarboxylase- and acetoin-positive. No endospores or spores are formed. Colonies on agar are circular. Temperature range for growth is $4-37^{\circ} \mathrm{C}$ (optimum growth occurs at $\left.25-30{ }^{\circ} \mathrm{C}\right) ; \mathrm{pH}$ range for growth is 6.5-8.0 (optimum, approx. $\mathrm{pH} 7 \cdot 0$ ); $\mathrm{NaCl}$ concentrations for growth are in the range $0-60 \mathrm{~g} \mathrm{l}^{-1}$ (optimum, $5 \mathrm{~g} \mathrm{NaCl}$ $\left.1^{-1}\right)$. Hydrostatic pressure for growth is in the range $0 \cdot 1-50 \mathrm{MPa}$ at $30^{\circ} \mathrm{C}$ (optimum, $10 \mathrm{MPa}$ ). Under optimal growth conditions, the doubling time of strain $\mathrm{LT}_{13} \mathrm{a}^{\mathrm{T}}$ is $45 \mathrm{~min}$ with agitation for a maximum cell density of $1 \times 10^{8}$ cells $\mathrm{ml}^{-1}$. Maltose, mannose, arabinose, sorbitol, succinate, glutamate, fumarate, citrate, lactate, pyruvate, yeast extract, peptone and tryptone are used as sole carbon and energy sources. Anaerobic growth occurs by fermentation of tryptone, peptone, yeast extract and pyruvate. Acids formed by fermentation of pyruvate are acetate, lactate and succinate. Strain $\mathrm{LT}_{13} \mathrm{a}^{\mathrm{T}}$ uses oxygen, nitrate, ferric iron, fumarate and cystine as terminal electron acceptors with lactate as electron donor. On the basis of 16S rRNA gene sequence analysis, the strain belongs to the $\gamma$ Proteobacteria and is a member of the genus Shewanella. $\mathrm{Q}_{7}, \mathrm{Q}_{8}, \mathrm{MK}_{7}, \mathrm{MMK}_{7}$ and $\mathrm{MMK}_{8}$ are present. Major polar lipids present are phosphatidylethanolamine and phosphatidylglycerol. Major fatty acids are $16: 1 \omega 7 c$, 15:0 iso, 16:0 and 13:0 iso. Polyunsaturated fatty acids 
(e.g. $20: 5 \omega 3 c$ ) are not present. The $\mathrm{G}+\mathrm{C}$ content of the DNA is $44.9 \mathrm{~mol} \%$.

The type strain is $\operatorname{LT}_{13} \mathrm{a}^{\mathrm{T}}\left(=\mathrm{DSM} 15900^{\mathrm{T}}=\mathrm{JCM} 12080^{\mathrm{T}}\right)$ and was isolated from deep marine sediment at the Nankai Trough, off the coast of Japan in the Pacific Ocean (Ocean Drilling Program, Leg 190).

\section{Acknowledgements}

We thank the Ocean Drilling Program and John Parkes and Barry Cragg (University of Bristol) for Leg 190 sediment samples. We also acknowledge Julian Marchesi and Jens Kallmeyer for their help with preparation and sample handling. L. T. would like to thank Stéphane L'Haridon for culture advice and Gérard Sinquin for electron microscope pictures. This work was funded by European Union project DeepBUG (contract number EVK3-CT-1999-017).

\section{References}

Akagawa-Matsushita, M., Itoh, T., Katayama, Y., Kuraishi, H. \& Yamasato, K. (1992). Isoprenoid quinone composition of some marine Alteromonas, Marinomonas, Deleya, Pseudomonas and Shewanella species. J Gen Microbiol 138, 2275-2281.

Bale, S. J., Goodman, K., Rochelle, P. A., Marchesi, J. R., Fry, J. C., Weightman, A. J. \& Parkes, R. J. (1997). Desulfovibrio profundus sp. nov., a novel barophilic sulfate-reducing bacterium from deep sediment layers in the Japan Sea. Int J Syst Bacteriol 47, 515-521.

Bozal, N., Montes, M. J., Tudela, E., Jiménez, F. \& Guinea, J. (2002). Shewanella frigidimarina and Shewanella livingstonensis sp. nov. isolated from Antarctic coastal areas. Int J Syst Evol Microbiol 52, 195-205.

Brettar, I. \& Höfle, M. G. (1993). Nitrous oxide producing heterotrophic bacteria from the water column of the central Baltic: abundance and molecular identification. Mar Ecol Prog Ser 94, 253-265.

Brettar, I., Christen, R. \& Höfle, M. G. (2002). Shewanella denitrificans sp. nov., a vigorously denitrifying bacterium isolated from the oxicanoxic interface of the Gotland Deep in the central Baltic Sea. Int J Syst Evol Microbiol 52, 2211-2217.

Cragg, B. A., Bale, S. J. \& Parkes, R. J. (1992a). A novel method for the transport and long-term storage of cultures and samples in an anaerobic atmosphere. Lett Appl Microbiol 15, 125-128.

Cragg, B. A., Harvey, F. M., Fry, J. C., Herbert, R. A. \& Parkes, R. J. (1992b). Bacterial biomass and activity in the deep sediment layers of the Japan Sea, Hole 798B. In Proceedings of the Ocean Drilling Program, Scientific Results, Leg 128, pp. 761-776. College Station, TX: Texas A\&M University.

DeLong, E. F., Franks, D. G. \& Yayanos, A. A. (1997). Evolutionary relationships of cultivated psychrophilic and barophilic deep-sea bacteria. Appl Environ Microbiol 63, 2105-2108.

Erauso, G., Charbonnier, F., Barbeyron, T., Forterre, P. \& Prieur, D. (1992). Preliminary characterization of a hyperthermophilic archaebacterium with a plasmid, isolated from a North Fiji Basin hydrothermal vent. C R Acad Sci Ser III Sci Vie 314, 387-393.

Felsenstein, J. (1985). Confidence limits on phylogenies: an approach using the bootstrap. Evolution 39, 783-791.

Ghosh, D., Bal, B., Kashyap, V. K. \& Pal, S. (2003). Molecular phylogenetic exploration of bacterial diversity in a Bakreshwar (India) hot spring and culture of Shewanella-related thermophiles. Appl Environ Microbiol 69, 4332-4336.
Ivanova, E. P., Sawabe, T., Hayashi, K., Gorshkova, N. M., Zhukova, N. V., Nedashkovskaya, O. I., Mikhailov, V. V., Nicolau, D. V. \& Christen, R. (2003). Shewanella fidelis sp. nov., isolated from sediments and sea water. Int J Syst Evol Microbiol 53, 577-582.

Jensen, M. J., Tebo, B. M., Baumann, P., Mandel, M. \& Nealson, K. H. (1980). Characterization of Alteromonas hanedai (sp. nov.), a nonfermentative luminous species of marine origin. Curr Microbiol 3, 311-315.

Jukes, T. H. \& Cantor, C. R. (1969). Evolution of protein molecules. In Mammalian Protein Metabolism, pp. 21-132. Edited by H. N. Munro. New York: Academic Press.

Kato, C. \& Nogi, Y. (2001). Correlation between phylogenetic structure and function: examples from deep-sea Shewanella. FEMS Microbiol Ecol 35, 223-230.

Kato, C., Sato, T. \& Horikoshi, K. (1995). Isolation and properties of barophilic and barotolerant bacteria from deep-sea mud samples. Biodivers Conserv 4, 1-9.

Koroleff, F. (1969). Direct determination of ammonia in natural waters as indophenol blue. In Information on Techniques and Methods for Seawater Analysis, pp. 19-22. Charlottenlund, Denmark: International Council for the Exploration of the Sea.

Lake, J. A. (1987). A rate-independent technique for analysis of nucleic acid sequences: evolutionary parsimony. Mol Biol Evol 4, 167-191.

Leonardo, M. R., Moser, D. P., Barbieri, E., Brantner, C. A., MacGregor, B. J., Paster, B. J., Stackebrandt, E. \& Nealson, K. H. (1999). Shewanella pealeana sp. nov., a member of the microbial community associated with the accessory nidamental gland of the squid Loligo pealei. Int J Syst Bacteriol 49, 1341-1351.

Lucas, S., Toffin, L., Zivanovic, Y., Charlier, D., Moussard, H., Forterre, P., Prieur, D. \& Erauso, G. (2002). Construction of a shuttle vector for, and spheroplast transformation of, the hyperthermophilic archaeon Pyrococcus abyssi. Appl Environ Microbiol 68, 5528-5536.

Ludwig, W., Strunk, O., Westram, R. \& 29 other authors (2004). ARB: a software environment for sequence data. Nucleic Acids Res 32, 1363-1371.

MacDonell, M. T. \& Colwell, R. R. (1985). Phylogeny of the Vibrionaceae, and recommendation for two new genera, Listonella and Shewanella. Syst Appl Bacteriol 6, 171-182.

Maidak, B. L., Cole, J. R., Lilburn, T. G. \& 7 other authors (2001). The RDP-II (Ribosomal Database Project). Nucleic Acids Res 29, 173-174.

Makemson, J. C., Fulayfil, N. R., Landry, W., Van Ert, L. M., Wimpee, C. F., Widder, E. A. \& Case, J. M. (1997). Shewanella woodyi sp. nov., an exclusively respiratory luminous bacterium isolated from the Alboran Sea. Int J Syst Bacteriol 47, 1034-1039.

Marteinsson, V. T., Watrin, L., Prieur, D., Caprais, J. C., Raguénès, G. \& Erauso, G. (1995). Phenotypic characterization, DNA similarities, and protein profiles of twenty sulfur-metabolizing hyperthermophilic anaerobic archaea isolated from hydrothermal vents in the southwestern Pacific Ocean. Int J Syst Bacteriol 45, 623-632.

Mikucki, J. A., Liu, Y., Delwiche, M., Colwell, F. S. \& Boone, D. R. (2003). Isolation of a methanogen from deep marine sediments that contain methane hydrates, and description of Methanoculleus submarinus sp. nov. Appl Environ Microbiol 69, 3311-3316.

Moore, E. R. B., Arnscheidt, A., Krüger, A., Strömpl, C. \& Mau, M. (1995). Simplified protocols for the preparation of genomic DNA from bacterial cultures. In Molecular Microbial Ecology Manual, Supplement 4, pp. 1.6.1.1-1.6.1.15. Edited by A. D. L. Akkermans, J. D. van Elsas \& F. J. de Bruijn. Dordrecht: Kluwer.

Moore, G. F., Taira, A., Klaus, A. \& 23 other authors (2001). Deformation and fluid flow processes in the Nankai Trough 
accretionary prism sites 1173-1178. In Proceedings of the Ocean Drilling Program, Initial Reports, vol. 190. College Station, TX: Texas A\&M University.

Moser, D. P. \& Nealson, K. H. (1996). Growth of the facultative anaerobe Shewanella putrefaciens by elemental sulfur reduction. Appl Environ Microbiol 62, 2100-2105.

Myers, C. R. \& Nealson, K. H. (1988). Bacterial manganese reduction and growth with manganese oxide as the sole electron acceptor. Science 240, 1319-1321.

Myers, C. R. \& Nealson, K. H. (1990). Respiration-linked proton translocation coupled to anaerobic reduction of manganese (IV) and iron(III) in Shewanella putrefaciens MR-1. J Bacteriol 172, 6232-6238.

Nogi, Y., Kato, C. \& Horikoshi, K. (1998). Taxonomic studies of deep-sea barophilic Shewanella strains and description of Shewanella violacea sp. nov. Arch Microbiol 170, 331-338.

Parkes, R. J., Cragg, B. A., Bale, S. J., Goodman, K. \& Fry, J. C. (1995). A combined ecological and physiological approach to studying sulphate reduction within deep marine sediment layers. J Microbiol Methods 23, 235-249.

Pfennig, N., Widdel, F. \& Trüper, H. G. (1981). The dissimilatory sulfate-reducing bacteria. In The Prokaryotes, pp. 926-940. Edited by M. P. Starr, H. Stolp, H. G. Trüper, A. Balows \& H. G. Schlegel. New York: Springer.

Saitou, N. \& Nei, M. (1987). The neighbor-joining method: a new method for reconstructing phylogenetic trees. Mol Biol Evol 4, 406-425.

Satomi, M., Oikawa, H. \& Yano, Y. (2003). Shewanella marinintestina sp. nov., Shewanella schlegeliana sp. nov. and Shewanella sairae sp. nov., novel eicosapentaenoic-acid-producing marine bacteria isolated from sea-animal intestines. Int J Syst Evol Microbiol 53, 491-499.

Semple, K. M. \& Westlake, D. W. S. (1987). Characterization of ironreducing Alteromonas putrefaciens strains from oil field fluids. Can J Microbiol 33, 366-371.
Slobodkin, A. I., Tourova, T. P., Kuznetsov, B. B., Kostrikina, N. A., Chernyh, N. A. \& Bonch-Osmolovskaya, E. A. (1999). Thermoanaerobacter siderophilus sp. nov., a novel dissimilatory $\mathrm{Fe}(\mathrm{III})$ reducing, anaerobic, thermophilic bacterium. Int J Syst Bacteriol 49, 1471-1478.

Solorzano, L. (1969). Determination of ammonia in natural waters by the phenol-hypochlorite method. Limnol Oceanogr 14, 799-801.

Stackebrandt, E. \& Goebel, B. M. (1994). Taxonomic note: a place for DNA-DNA reassociation and 16S rRNA sequence analysis in the present species definition in bacteriology. Int J Syst Bacteriol 44, 846-849.

Tindall, B. J. (1990a). A comparative study of the lipid composition of Halobacterium saccharovorum from various sources. Syst Appl Microbiol 13, 128-130.

Tindall, B. J. (1990b). Lipid composition of Halobacterium lacusprofundi. FEMS Microbiol Lett 66, 199-202.

Venkateswaran, K., Dollhopf, M. E., Aller, R., Stackebrandt, E. \& Nealson, K. H. (1998). Shewanella amazonensis sp. nov., a novel metal-reducing facultative anaerobe from Amazonian shelf muds. Int J Syst Bacteriol 48, 965-972.

Venkateswaran, K., Moser, D. P., Dollhopf, M. E. \& 10 other authors (1999). Polyphasic taxonomy of the genus Shewanella and description of Shewanella oneidensis sp. nov. Int J Syst Bacteriol 49, 705-724.

Wery, N., Moricet, J.-M., Cueff, V., Jean, J., Pignet, P., Lesongeur, F., Cambon-Bonavita, M.-A. \& Barbier, G. (2001). Caloranaerobacter azorensis gen. nov., sp. nov., an anaerobic thermophilic bacterium isolated from a deep-sea hydrothermal vent. Int J Syst Evol Microbiol 51, 1789-1796.

Widdel, F. \& Bak, F. (1992). Gram-negative mesophilic sulfatereducing bacteria. In The Prokaryotes, 2nd edn, pp. 3352-3378. Edited by A. Balows, H. G. Trüper, M. Dworkin, W. Harder \& K. H. Schleifer. New York: Springer.

Ziemke, F., Höfle, M. G., Lalucat, J. \& Rosselló-Mora, R. (1998). Reclassification of Shewanella putrefaciens Owen's genomic group II as Shewanella baltica sp. nov. Int J Syst Bacteriol 48, 179-186. 